this investigation in older children and adults seems to be reasonably safe in this regard despite the high total doses which may be given. Free aortic injection of contrast is also usually safe now that sodium acetrizoate is no longer used. ${ }^{18}$ With selective renal arteriography the likelihood of renal injury is greater, even with present-day media. Details of techniques are often significant here. It is, for example, important to limit the volume and concentration of contrast medium in any one injection and to avoid prolonged occlusion of small or stenotic arteries by the catheter. Such points are generally well recognized, but it is less widely known that there is strong experimental evidence of the protective value of the routine production of a diuresis during an aortogram. 1920 Theoretically this involves setting up a $5 \%$ dextrose drip before aortography, but as the main danger is from selective arteriography the rapid infusion of the solution through the aortic catheter at the outset of the examination is likely to be adequate in most cases.

The protective effect of a diuresis against many types of renal injury is one of the principal measures which may be employed to reduce the risk of it from contrast media. It would appear reasonable to suggest that the preparation of the patient for oral cholecystography and intravenous cholangiography should include an instruction to drink freely. In the situations known to carry a higher risk of renal damage -with double dosage or when there is jaundice or renal failure-the need for the examination should be carefully reconsidered, and a mannitol infusion may be thought advisable. The present trend towards drip infusion cholangiography can be turned to advantage here if large volumes of fluid are used in the drip. It should also become accepted practice that intravenous cholangiography is not undertaken less than four days and preferably a week after an oral cholecystogram.

In urography the main need is to avoid dehydration of infants and patients in renal failure and to limit dosage in infancy. If these precautions are all accepted as a routine, it seems reasonable to hope that the renal complications from these examinations will become even less frequent than at present.

${ }^{1}$ McEvoy, J., McGeown, M. G., and Kumar, R., British Medical Fournal, 1970, 4, 717.

Seaman, W. B., Cosgriff, S., and Wells, J., American fournal of Roentgenology, 1963, 90, 859.

3 Setter, J. G., Maher, J. F., and Schreiner, G. E., Fournal of the American Medical Association, 1963, 184, 102.

Wennberg, J. E., et al., fournal of the American Medical Association, 1963, 186, 461 .

Canales, C. O., Smith, G. H., Robinson, J. C., Remmers, A. R., and Sarles, H. E., New England fournal of Medicine, 1969, 281, 89.

6 Craft, I. L., and Swales, J. D., British Medical fournal, 1967, 2, 736. 7 Finby, N.,, and Blasberg, G., Gastroenterology, 1964, 46, 276

8 Ansell, G., British fournal of Radiology, 1970, 43, 910 .'

Fulton, R. E., Witten, D. M., and Wagoner, R. D., American fournal of Roentgenology, 1969, 106, 623 .
of

10 Davidson, A. J., Becker, J., Rothfield, N., Unger, G., and Ploch, D. R., Radiology, 1970, 97, 249.

11 Brown, C. B., Glancy, J. J., Fry, I. K., and Cattell, W. R., Lancet, $1970,2,952$.

12 Bergman, L. A., Ellison, M. R., and Dunea, G., New England fournal of Medicine, 1968, 279, 1277 .

Pillay, V. K. G., Rollins, P. C., Schwartz, F. D., and Kark, R. M., Radiology, 1970, 95, 633 .

it Cwynarski, M. T., and Saxton, H. M., British Medical fournal, 1969, $1,486$.

15 Lasser, E. C., Lang, J. H., and Zawadzki, Z. A., fournal of the American Medical Association, 1966, 198, 945.

16 Ansell, G., British Fournal of Radiology, 1970, 43, 395.

Gruskin, A. B., et al., Fournal of Pediatrics, 1970, 76, 41

Walsh, P. C., Gittes, R. F., and Lecky, J. W., jun., Radiology, 1970, 97, 33.

19 Morris, G. C., jun., Crawford, E. S., Beall, A. C., jun., and Moyer. J. H., Surgical Forum, 1957, 7, 319.

${ }^{20}$ Rhea, W. G., jun., Killen, D. A., and Foster, J. H., Archives of Surgery, 1964, 89, 294.

\section{Freezing the Prostate}

The selective destruction of tissue with low temperatures has been found clinically useful in neurosurgery. ${ }^{1}$ In 1965 M. J. Gonder and colleagues ${ }^{2}$ showed that avascular areas could be produced in the prostate in dogs by applying extreme cold, and subsequently they developed a practical application of this for the treatment of both benign and malignant diseases of the prostate in man.

The low temperature is delivered to the prostate by means of an insulated probe like a cystoscope, which is passed through the urethra. The freezing unit is positioned in the prostatic urethra with the aid of a finger in the rectum after the bladder has been filled with air to remove its walls from the tip of the probe. Liquid nitrogen, or less commonily nitrous oxide, is used to cool the probe to -160 to $-180^{\circ} \mathrm{C}$ $\left(-90^{\circ} \mathrm{C}\right.$ for nitrous oxide) and the temperature of the prostatic tissue is reduced to between -20 and $-40^{\circ} \mathrm{C}$. Thermocouple needles may be used to monitor the temperature of the prostate and surrounding tissues and to ensure that the temperature of the rectal mucosa does not drop below $0^{\circ} \mathrm{C}$. The size and vascularity of the gland will determine the length of the freezing time, which is usually between 5 and 20 minutes.

This procedure causes haemorrhage, inflammation, and necrosis in the prostate. ${ }^{34}$ After two weeks the inflammation subsides and areas of squamous metaplasia develop, the significance of which is ill understood in these circumstances. Advocates of the operation have suggested that its main advantages are that a general anaesthetic, though desirable, is not essential, immediate loss of blood is minimal, and that postoperatively it is relatively painless, bloodless, and allows early ambulation. Thus it has been put forward as a safer alternative to the more orthodox methods of dealing with prostatic enlargement in elderly or infirm patients with cardiopulmonary disease and in those with bleeding tendencies.

However, an analysis of reported series, ${ }^{4-13}$ even when the poor condition of the patients is taken into account, shows a considerable mortality and morbidity. The mortality attributable to the cryoprostatectomy ranges between 2 and $12 \%$. Prolonged periods of catheter drainage are common. Many patients have a catheter for over two weeks and some for longer periods. A complication inherent in the method is the retention of pieces of partially sloughed prostate in the bladder and prostatic cavity. To remove them subsequent transurethral resection is needed in a number of cases. To overcome this a small resection has been incorporated in the initial freezing session, ${ }^{910}$ but this manoeuvre would seem to defeat the purpose of the conservative approach. Instillation of proteolytic enzymes into the bladder to remove the slough has not been effective. ${ }^{10}$ High in the list of complications are permanent incontinence and infections of the urinary tract, with subsequent Gram-negative septicaemia. ${ }^{12} 13$ Other less common but none the less incapacitating complications include pyonephrosis, periprostatic abscess, rectal and bladder injury, osteitis pubis, urethral stricture, and epididymitis.

Details of the ability of the patients to pass urine satisfactorily after cryosurgery are generally lacking, ${ }^{41213}$ and in the patients with eventual satisfactory voiding it is sometimes not clear what other treatment was necessary as well. Excellent results are reported in some series in as high as $60-80 \%$, ${ }^{9-11}$ but in two of these series a small transurethral resection was also incorporated. ${ }^{910}$ Blood loss is certainly less than for conventional forms of prostatectomy, ${ }^{414}$ but patients on 
anticoagulants are not free from the risk of profuse haematuria. ${ }^{12}$

It is difficult to imagine cryoprostatectomy becoming more popular in its present form, and indeed it has been abandoned in some centres after poor (unpublished) results. Its success must always depend on the size, shape, and vascularity of the prostate gland and on the need to freeze just enough tissue for just long enough without damaging the surrounding organs and sphincter areas.

Anaesthesia has reached a sufficiently high standard for few patients to be so ill that they cannot withstand the short anaesthetic necessary for a palliative transurethral resection. In these the operation need provide only a "channel" sufficient to allow adequate urination for what must inevitably be a limited life expectancy. Even the presence of a cardiac pacemaker need not be a contraindication to resection. ${ }^{15}$

An interesting consequence of cryosurgery is the "immunocryothermic response" that has been observed in some patients with metastatic carcinoma of the prostate. ${ }^{16}$ Prostatic autoantibodies have been detected, and their production is boosted by a second freeze at an interval of 30 days. The production of prostatic tumour-specific antibodies might lead to a further line of attack on these tumours.

1 Cooper, I. S., New England Fournal of Medicine, 1963, 268, 743.

Gonder, M. J., Soanes, W. A., and Smith, V., Annals of the New York Academy of Sciences, 1965, 125, 716

Ehrlich, R. M., Tannenbaum, M., Roberts, M., and Lattimer, J. K., Fournal of Urology, 1969, 101, 890.

Soanes, W. A., Gonder, M. J., Albin, R. J., Maser, M. D., and Jagodzinski, R. V., Fournal of Cryosurgery, 1969, 2, 23.

Ortved, W. E., O'Ǩelly, F. M., Todd, I. A. D., Maxwell, J. B., and Sutton, M. R., British fournal of Urology, 1967, 39, 577.

- Dow, J. A., fournal of Urology, 1968, 100, 66.

Dowd, J. B., Flint, L. D., Zinman, L. N., and Tripathi, V. N. P., Surgical Clinic of North America, 1968, 48, 627.

- Marshall, A., Procecdings of the Royal Society of Medicine, 1968, 61, 1139.

- Jordan, W. P., Walker, D., Miller, G. H., and Drylie, D. M., Fournal of Cryosurgery, 1968, 1, 130.

10 Hansen, R. I., Lund, F., and Backer, O. G., Urologia Internationalis, 1969, 24, 160.

11 Sesia, G., Ferrando, V., and Laudi, M., International Surgery, 1970, 53, 82.

12 Green, N. A., British fournal of Urology, 1970, 42, 10.

1s Gill, W., Fraser, Sir J., Long, W., and Lee, P., Surgery, Gynecology and Obstetrics, 1970, 131, 877.

Walker, D., Jordan, W. P., jun., Drylie, D. M., and Miller, G. H., fournal of Urology, 1968, 100, 188

15 Fein, R. L., fournal of Urology, 1967, 97, 137.

16 Albiin, R. J., Soanes, W. A., and Gonder, M. J., International Surgery, $1969,52,8$.

\section{Congenital Dislocation of the Hip}

Since pioneer work in Italy and Sweden, and in Britain notably by T. G. Barlow, ${ }^{1}$ congenital dislocation of the hip is being diagnosed in the first fortnight of life. The frequency of neonatal diagnosis is about 4 per 1,000 live births-four times as high as the frequency of late diagnosis cases in Sweden and Britain. Recently it has become clear that the discrepancy is due to the fact that of every four cases of dislocation of the hip picked up in the neonatal period three would recover spontaneously. In Edinburgh, for example, where neonatal diagnosis has been attempted for a decade, the incidence of late diagnosis patients has now dropped to little more than 1 in $10,000 .^{2}$ Since neonatal treatment is so simple compared to later treatment the overtreatment of neonatal patients is well worthwhile.

Much of the work on causation is based on studies of late diagnosis cases, such as that summarized by $C$. $O$. Carter and J. A. Wilkinson. ${ }^{3}$ They noted the evidence for two environmental factors and two genetic factors-generalized joint laxity (probably single gene determined) and acetabular dysplasia (likely to be polygenic). One environmental factor was prenatal-the intrauterine malposition of flexed hips and extended knees, often but not necessarily associated with breech presentation; the other was postnatal-the tendency to swaddle the child with hips adducted and extended.

What, however, is the nature of the cases which correct themselves? A recent extensive family study from Edinburgh by Ruth Wynne-Davies ${ }^{24}$ has thrown some ligh: on this. There was about twice as high a proportion of boys among the neonatal patients as among those diagnosed late. The family study, however, indicated an essential similarity of the two conditions: of the sibs of the neonatal cases, mostly born since 1960, 13\% had a diagnosis (mostly neonatal) of hip dislocation. These proportions of first degree relatives affected are similar to those in earlier studies in Birmingham ${ }^{5}$ and London ${ }^{6}$ when allowance is made for the increased frequency of neonatal diagnosis. There were, however, differences between the two groups in the relative contributions of the two genetic factors. Acetabular dysplasia was clearly seen, as measured on radiographs, in the parents of the late diagnosis cases, while in the parents of neonatal cases the signs of acetabular abnormality were less marked and not significantly different from the control series. Joint laxity, however, was more often found in both patients with the neonatal form and their first degree relatives.

Wynne-Davies suggests, therefore, that familial joint laxity plays a relatively greater part in the cases of congenital dislocation of the hip which recover spontaneously, and that acetabular dysplasia is relatively more important in the cases which, before the introduction of neonatal treatment, used to persist and present as late diagnosis cases. This would fit with her observation that the female preponderance is less marked among the neonatal patients, especially as persistent joint laxity plays a bigger part in causing hip dislocation in boys than in girls. ${ }^{7}$ It would also fit with the observation ${ }^{8}$ that among late diagnosis patients those with acetabular dysplasia respond less well to conservative treatment.

As a practical problem in paediatrics congenital dislocation of the hip is largely solved where practitioners skilled in neonatal examination and treatment are to hand. There is no way yet to distinguish the majority of neonatal patients who will recover spontaneously, and so all should be treated. Where resources for neonatal examination are limited there is a case for paying special attention to the sibs and offspring of known cases, since their chance of having the disorder is some 25 times the random risk. It should, however, be borne in mind that where a substantial degree of acetabular dysplasia is contributing to the dislocation (and this cannot be measured neonatally) this dysplasia is likely to persist and may cause early osteoarthritis. 910 Long-term follow-up of neonatal cases to look for this is needed. It may even be the case that prophylactic surgery may be desirable to improve the cover of the femoral head by the roof of the acetabulum if there are instances where considerable acetabular dysplasia becomes apparent after neonatal treatment.

1 Barlow, T. G., fournal of Bone and foint Surgery, 1962, 44B, 292.

2 Wynne-Davies, R., fournal of Medical Genetics, 1970, 7, 315.

3 Carter, C. O., and Wilkinson, J. A., Clinical Orthopedics, 1964a, 33, 119.

Wynne-Davies, R., fournal of Bone and foint Surgery, 1970, 52B, 704. Record, R. G., and Edwards, J. H., British fournal of Social and Preventive Medicine, 1958, 12, 8.

6 Carter, C. O., in Counselling and Progress in Medical Genetics, ed. A. G. Motulsky. New York, Hoeber. In press.

7 Carter, C. O., and Wilkinson, J. A., fournal of Bone and foint Surgery, $1964,46 \mathrm{~B}, 40$

8 Wilkinson, J. A., and Carter, C. O., fournal of Bone and foint Surgery, $1960,42 \mathrm{~B}, 669$.

9 Wiberg, G., fournal of Bone and foint Surgery, 1953, 35A, 65. Lloyd-Roberts, G. C., fournal of Bone and foint Surgery, 1955, 37B,
8. 